\title{
GEOCHEMICAL ECOLOGY IN THE ENVIRONMENTAL PROTECTION
}

\author{
Prof. dr Slobodan Stefanovic ${ }^{1}$, Prof. dr Radoje Cvejic ${ }^{2}$, dr Dragoslav Ilic ${ }^{3}$, dr Vladan Vucic ${ }^{4}$ \\ ${ }^{1}$ Higher School of Applied Professional Studies, Vranje, Serbia. slobodanstef@gmail.com \\ ${ }^{2}$ Associate Professor, Faculty of strategic and operational management, Belgrade, Serbia. \\ drradojecvejic@gmail.com \\ ${ }^{3}$ Public Utility Company "Water" Zajecar, Serbia. dragoslav.dragi@gmail.com \\ ${ }^{4}$ YUMIS L.T.D. Nis, Serbia.vladan.vucuc@gmail.com
}

\begin{abstract}
Geochemical ecology is the study of the dependence of the places of residence life, environmental conditions and the conditions of existence, of the interaction of organisms and their communities with the geochemical environment in the biosphere as a unified system of organisms and the environment.
\end{abstract}

KEY WORDS: geochemical ecology, chemical element, environment, organisms.

\section{INTRODUCTION}

The aim of the study of interactions of organisms and the environment is explaining the process of adaptation to environmental conditions. Discovering the genetic nature of adaptation represent the basis understanding the evolution of species - variability, mutation, election, and selection.

Geochemical ecology studies the dependence of the variability of processes in the organisms (at different levels of complexity of organisms) of environmental factors and determine their adaptive character.

It is of great interest to study the role of individual elements of micro fertilizers or their combinations of the variability of physiological functions of plants and soil microflora.. This research are close to the experimental geochemical ecologytasks. Organic chemistry studies the impact of action of chemical factors on the biosphere, in which mainly concentrates on the study of the effects of toxic substances (pesticides, herbicides, defoliants) of organisms and compounds of mercury, cadmium, lead and others. Field of complex biological organisms to adapt to each other organisms and species and to live in communities (population - a community of individuals of a species; biocenosis - community of different species of animals, plants and micro-organisms), based on the production of the organisms in the phylogenies of natural chemical compounds signal character falls in ecological biochemistry.

One of the main problems is the geochemical ecology of migration and the role of chemical elements in the chain row: rocks, soil, plants and animals, and finally, a man with a medical condition changes. This problem actually involves two groups:

- contamination of organisms with toxic and carcinogenic substances;

- negative environmental impact of deficiency in essential biological elements as a result of geochemical processes or human activity.

The interdisciplinary study of this group of problems has led to important discoveries that have highlighted the close relationship between the trade deficit of some essential elements in rocks and soil and development of degenerative diseases in humans, including heart diseases and blood vessels, various types of malignant processes and endemic neuropathy (Maksimovic 1988; Maksimovic and others, 1989).

Endemic diseases caused by the lack or excess of certain micro-elements in the environment affect plants, animals and man. Sensitivity of organisms to varying degrees of lack or excess chemical elements determines the degree of vulnerability of the population in endemic ills: endemic goiter due to iodine deficiency or combination of iodine, cobalt and copper at the same time; ataxia due to copper deficiency; hypo or B12 deficiency disease caused by lack of cobalt; osteo-and chondrodystrophic due to excess strontium and calcium deficiency; entefiti due to excess boron, etc.. 


\section{MIGRATION OF CHEMICAL ELEMENTS}

The importance of the geochemical environment for the development and evolution of living organisms is determined by many chemical elements involved in exchange processes of matter and constitute the biologically active compounds. Therefore, the inhomogeneity of the geochemical environment is one of the major causes of variability of metabolism and synthesis of biologically active compounds in organisms. For example, animals that live in the regions that are close, but differ in the content of cobalt in the soil, in a different way, the synthesis of vitamin B12 by the microflora of the digestive tract, and the amount of this compound in organisms also vary.

A very important feature of the biosphere is the unity of the geochemical environment and life, which is established in the evolution of the biosphere and it is expressed in constant depending on the life of the geochemical conditions of the environment and climate (water regime, temperature, insolation, convection). Chemical mosaic unity of the biosphere and the geochemical environment and life open up avenues for the study of the biosphere region, which is characterized by involvement in the biogenic migration of chemical elements in certain quantities and relationships, which are a special regional standards, the composition of flora and fauna, as well as the response of organisms to chemical elements of the environment. The degree of accumulation of chemical elements is determined by not only the geochemistry of the environment and the biological nature of organisms, but also biogeochemical food chains (Figure 1.), which is realized through the links between organisms and the environment (rocks, soil, microorganisms, water, air, plants, animals, humans).

Microelements of the rocks

\begin{tabular}{|c|c|c|}
\hline $\begin{array}{c}\text { Micronutrient of } \\
\text { the soil }\end{array}$ & $\begin{array}{c}\text { Microelement } \\
\text { s of the air }\end{array}$ & $\begin{array}{c}\text { Microelements } \\
\text { of the water }\end{array}$ \\
\hline Plants & - & $\begin{array}{c}\text { Animals } \\
\text { animal origin }\end{array}$ \\
\hline $\begin{array}{c}\text { The nutrients of } \\
\text { plant origin }\end{array}$ & - \\
\hline \multicolumn{2}{|c|}{ Humans and animals organisms } \\
\hline
\end{tabular}

Figure 1. Biogeochemical food chains and migration of chemical elements (as Kovalski, 1970)
Legality of migration of chemical elements in the biosphere can not be understood, if do not identify pathways and processes of their concentration and exchange in organisms, organisms needs for trace elements, their concentration limits and nature of compounds that contain microelements, which are forms changing in the process of migration through the soil and water, living organisms, plants and animals. In addition to the food chain comes to sifting - to reduce the concentration of some chemical elements and storage - increase in the concentration of other elements. When studying these issues intersect in the domain of biochemistry and biogeochemistry. It is necessary to study the complex process of selective concentration of trace elements by plants and animals, the participation of microelements in the material exchange, the conditions and processes of synthesis in organisms, enzymes and other biologically active compounds that contain micronutrients, biochemical and physiological mechanisms of their biological activity, metabolism and variability of morphological characteristics in the case of different concentrations of chemical elements in the geochemical environment, the role of environmental factors in the geochemical evolution of organisms (natural selection, adaptation, education type).

\section{LEGALITY OF ACTIONS OF ENVIRONMENTAL FACTORS}

Every living organism can notmal thrive and reproduce only in a specific field values of environmental parameters. For the normal existence of land animals and peoplethere are minimal and maximal temperature limits, light, oxygen concentration in air, atmospheric pressure, etc. The area of quantitative values specified environmental parameters whose borders may exist individual given species (population) is called the range of existence, stability zone, zone of tolerance or biointerval environmental factor. Usually stands out zone normal vital activity and stress zones outside of which are the limits of endurance (stability). When the parameter value is out of these boundaries it leads to the death of the organism. 
At abscissa axis stands optimal intensity of environmental factors, characterized by the maximum degree of a favorable impact of the factor on the body. Optimum corresponds to a moderate pace of development of the organism with the minimum energy consumption when the lowest mortality rates, the longest life expectancy and high fertility of mature individuals.

For each plant and animal species, there are optimal zone of normal vital activity, stress areas and a threshold for each environmental factor. It is a fundamental biological principle.

Under natural conditions in every living organism, group of organisms and ecosystems at the same time is a large number of factors. Doing so may cause a synergetic effect when simultaneous action of several factors leading to the amplification of their individual effects. Possible the other way round - when due to the simultaneous action of several factors leads to the weakening of their overall operations. In such cases, the boundaries of endurance of organisms are changing. It should be emphasized that environmental factors can't be replaced with each other.

It is enough that the value of a single environmental factors out of the zone of optimum and to take the stress state of the organisms. In the case of major disturbances it lead to their extinction. This is called the limiting factor. This applies to all environmental factors. For example, both excess and lack of moisture can lead to the extinction of plants.

Assessment of the effects of different environmental factors on human health is a complex process that requires a multidisciplinary approach to the study of the ecosystem (Kataranovski, 1997). In the study of the complex relationship that exists between exposure to environmental pollution and the effects on a living organism, it is necessary for each specific agent - pollutant collect relevant biological data, then the data on the relationship between dose - response, as well as the exposure. In this research, are indispensable testing in experimental animals, because they allow establishment of the relationship between the observed xenobiotics - pollutants and adverse effects and can greatly assist in the interpretation of biological monitoring data.
Under the biological monitoring it means monitoring the accumulation of pollutants or harmful substances in their tissues and organs, as well as in the appropriate biochemical, morphological, physiological and pathological changes in individuals or population-environmental changes in plants and animals. Biological monitoring provides a great opportunity to explore the impact of the environment on the body and monitoring the change of its status because it can detect the symptoms of pollution, ie. environmental effects. In the biological monitoring particularly important place takes the monitoring of flora and fauna using biological markers.

There are many detailed biological monitoring methodology published by various national and international institutions and organizations such as the Agency for Food and Drug Administration (Food and Drug Administration: Code of Federal Regulations, 1978), the Agency for the U.S. Environmental Protection (Environmental Protection Agency: Federal Register, 1983), the Organization for Economic Cooperation and Development (OECD Guidelines for testing of chemicals). In these publications, for example, recommendations for the measurement of various parameters for the detection of possible organ damage in laboratory rats (Rattus norvegicus). And other laboratory animals (mice, rabbits, and others) are suitable for testing the toxic effects of various chemicals.

The subject of the study of ecology should be the body, considered in their midst. Chemical bonds of each organism to the environment in the biosphere are achieved not only through food chains and biogeochemical migration of chemical elements of soil, water, air and food chain organisms, but also depend on the unification of the organisms in the community, such as population and biocenosis.

\section{CHEMICAL ELEMENTAL COMPOSITION OF ORGANISMS}

Until now conclusively established that many microelements are essential for plant life, animals and humans. In their absence, or excess disturbs metabolism and disease. Such elements include copper, cobalt, zinc, manganese, iodine, molybdenum, selenium, fluoride, strontium, 
boron, cadmium, vanadium. Practical application in animal husbandry have iodine, cobalt, copper, zinc, manganese, molybdenum, selenium and fluoride for which are determined specific norms needs for certain kinds of domestic animals. Also, certain norms and the implementation of some trace elements (copper, manganese, zinc, molybdenum, boron) in fertilizers (Kovalski, Andrianov, 1970).

From the theoretical point of view the application of trace elements in livestock and crop production requires further study, which is primarily related to the role of less-studied elements, such as cadmium, chromium, strontium, boron, beryllium, nickel, vanadium, lithium, rubidium, cesium, barium, aluminum, scandium, gallium, germanium, arsenic, niobium.

One of the most important tasks of biogeochemistry and geochemical ecology is determining the biological role of understudied micronutrients and their bioactive compounds that produce organisms. Solving these tasks enabled the success of analytical chemistry, which is part of organisms and biologically active compounds isolated from them discovered many rare chemical elements and their concentrations.

IN the composition of living organisms were quantified 66-68 elements. It was found that 47 of them are permanent components of the organism. These are biogenic chemical elements. Contemporary level of knowledge a list of mineral elements can be severely limited, since there is the possibility of discovering the biological role of new chemical elements. Quantitative characteristics of a number of trace element contents are not yet known or unreliable, which is why it is too early to draw final conclusions on the chemical elemental composition of living organisms. Nevertheless, some authors (Bowen, 1966) based on data from the literature determined differences of elementary chemical composition of marine and terrestrial plants, marine and terrestrial animals, bacteria, etc.

Now the chemical elements according to their importance of study of the mammals can be divided into three groups. Chemical elements of the first group $(\mathrm{O}, \mathrm{C}, \mathrm{H}, \mathrm{N}, \mathrm{Ca}, \mathrm{P}, \mathrm{K}, \mathrm{S}, \mathrm{Ci}, \mathrm{Na}$, $\mathrm{Mg}, \mathrm{Zn}, \mathrm{Fe}, \mathrm{Cu}, \mathrm{J}, \mathrm{Mn}, \mathrm{V}, \mathrm{Mo}, \mathrm{Co}, \mathrm{Se})$, has been found in organisms participate in the exchange of goods, are part of the chemical compounds, including biologically active compounds (eg.ferments, hormones, vitamins, pigments). These elements are indispensable to life. Other groups of chemical elements $(\mathrm{Sr}, \mathrm{Cd}$, $\mathrm{Br}, \mathrm{F}, \mathrm{B}, \mathrm{Si}, \mathrm{Cr}, \mathrm{Be}, \mathrm{Ni}, \mathrm{Li}, \mathrm{Cs}, \mathrm{Sn}, \mathrm{Al}, \mathrm{Ba}, \mathrm{Rb}$, Ti, Ag, Ga, Ge, As, Hg, Pb, Bi , Sb, U, Th, Ra) are also constantly found in the organisms, but the shapes of their relationship is still poorly known, and their physiological and biochemical role is poorly known or unknown.

The content of biogenic elements in mammalian organisms shows that can change the chemical composition of organisms depending on the type and composition of the environment, ecology, season and time of day.

The third group consists of elements that are found within mammalian organisms, but their concentrations were not studied, nor know their biological role (Sc, Ti, Nb, Y, In, Te, La, Pr, Nd, Sm, Eu, Tb, W, Re).

It is attempted to determine the legality of the distribution of chemical elements, important and indispensable for living organisms in the Mendeleyev table.

A. P. Vinogradov (1944) has shown that in general terms there is one law for the distribution of chemical elements in the lithosphere and biosphere, and the chemical composition of living organisms and materials reflects the chemical composition of the environment. It is found that the quantitative content of some chemical elements in living matter is inversely proportional to their atomic mass (or atomic number). For the first 50-60 chemical elements already determined the periodicity of their quantitative content in living matter, corresponding to the periods Mendeleyev table.

Many times there was an attempt to determine why organisms use certain elements to create living matter and life processes. Thus, W.-L. R. Show (1960), based on the known fact that the periodic table is the most perfect classification of all atoms that exist in nature, comparing their electronic structure, atomic mass and atomic number of the physicochemical properties of living matter and the ability to use Ito in the life processes. Compared and

physicochemical properties of atoms permit the identification of those characteristics that are important for living organisms. Decisive role in 
this is a combination of different properties of a given atom $\mathrm{i}$ and the availability of External organisms in the environment.

In table 1.it is presented periodic table in which the labeled elements are necessary for life ${ }^{34}$ True, the idea of these elements varies with the determination of the biological role of new elements. However, basis on Mendeleyev table with relative certainty can predict where the elements can be expected detection of biological roles. So, for example, on the basis of beryllium in the table of elements can expect his participation in various enzyme systems; vanadium probably enters into the oxidationreduction systems of various tissues, it can be assumed that chromium and nickel, became part of yet unknown elements; biological role of titanium and scandium can be surprisingly important; coordination gallium compounds may have properties of the enzyme and so on.

Geochemical studies the ecology of organisms in unity with the natural geochemical environment in terms of low, normal and high content of a particular element in it, and change their attitude. Her role in determining the biological significance of new chemical elements is enormous. Under these conditions, different natural reservoir of chemical elements in the body to determine the connection of cause and effect changes depending on the shape of their compounds and participation in the processes of metabolism (matter exchange).

H. R. Show (1960), based on the known fact that the periodic table is the most perfect classification of all atoms that exist in nature, comparing their electronic structure, atomic mass and atomic number of the physicochemical properties of living matter and the ability to use atoms in the life processes. Compared and physicochemical properties of atoms permit the identification of those

\footnotetext{
${ }^{34}$ Although the preparation of the periodic table something that is routinely attributed to Mendeleyev, periodization and job elements has a much longer history. Already in the seventeenth century, precisely in 1661. The Robert Boyle lined up then known 13 elements in order of increasing relative atomic mass, and this system will extend Lavoisier an additional 11 elements. Yet the work of Mendeleyev periodzaciji elements will be remembered as the most important, there was because his solution of the periodic system really be more appropriate. In 1869 . He gives the first version of the periodic table of elements with layout similar to that of Njulendsa. This Mendeleyev layout table, was caused by the law of periodicity by which the physical and chemical performances of elements of periodic functions of their relative atomic weights.
}

characteristics that are important for living organisms. Decisive role in this is a combination of different properties of a given atom and the availability of External organisms in the environment.

\section{CONCLUSION}

Scientific and technological revolution is associated with continuous intensification and expanding economic activities of society. Due to the rising interest in environmental issues, especially the direct and indirect impact of production activities on the composition and properties of the atmosphere, the thermal regime of the planet, the level of radioactivity, pollution of the seas and oceans, reducing drinking water supplies, reducing supplies of renewable raw materials and energy resources, discharge the biosphere toxic waste and waste that can't be reprocessed biochemical, ecological impacts of anthropogenic, particularly urbanized, and the influence of environmental factors on physical and mental health of humans and the gene pool of the human population, and so on.

Ecological thinking is reflected in the various proposals for a reorientation of technology and production. Some of them are associated with environmental pessimism concepts where the cause is scientific technical progress itself. Doctrine of "limited growth", stable development, sustainable development, the "steady state", find it necessary to severely restrict or completely stop the technological - economic development.

Others as a counterweight to this pessimistic assessment of the future development of humanity and perspective of the use of natural resources suggest a radical transformation of technology, freeing her from the failures that led to the pollution of the environment, the application of alternative science and technology, a model of closed production cycles, creating new technical devices and technological processes - transport, energy and others., acceptable from an environmental point of view.

Ecology is fundamentally altered scientific views of not only the natural but also the social sciences, creating new theoretical approaches and methodological orientations in different sciences, contributed to the formation of a new 
ecological thinking. Ecology using the system approach analyzes the environment as complex differentiated system, whose various components are in dynamic equilibrium, consider the biosphere of the Earth as humanity's ecological niche, linking the environment and human activity in unique system "nature - society" determines the impact of humans on the natural balance ecosystems, the question of management and streamlining the mutual relationship of man and nature.

Table 1. Periodic table of elements that can be found in nature (eighty eight elements)

\begin{tabular}{|c|c|c|c|c|c|}
\hline \multicolumn{6}{|c|}{ GROUP ELEMENTS } \\
\hline $\begin{array}{l}\text { Serial } \\
\text { number of } \\
\text { elements } \\
\text { (periods) }\end{array}$ & $\begin{array}{l}\text { Name of the } \\
\text { element }\end{array}$ & Elements label & $\begin{array}{l}\text { Serial } \\
\text { number of } \\
\text { elements } \\
\text { (periods) }\end{array}$ & $\begin{array}{l}\text { Name of the } \\
\text { element }\end{array}$ & Elements label \\
\hline 6. & Hydrogen & H /-259,2 & 41 & Niobium/1 & Nb /2415; 8,57 \\
\hline 7. & Helium & He & 42 & Molybdenum/1 & Mo /2625; 10,2 \\
\hline 8. & Lithium/1 & Li /186; 0,53 & 43 & Technetium & Tc /2704 \\
\hline 9. & Beryllium/3 & Вe /1280; 1,82 & 44 & Ruthenium/3 & Ru /2500; 12,2 \\
\hline 10. & Pine & B /2300; 2,3 & 45 & Rhodium/2 & Rh /1966; 12,4 \\
\hline 11. & Carbon/4 & C /3700; 2,2 & 46 & Palladium/2 & Pd /1554; 12,0 \\
\hline 12. & Nitrogen & $\mathrm{N} /-210,02$ & 47 & Silver/2 & Ag $/ 960 ; 10,49$ \\
\hline 13. & Oxygen & $O /-218,83$ & 48 & Cadmium/4 & $\mathrm{Cd} / 321 ; 8,65$ \\
\hline 14. & Fluorine & F /-120 & 49 & Indium/2 & In /156; 7,31 \\
\hline 15. & Neon & $\mathrm{Ne} / 248,6$ & 50 & Tin/2 and 4 & Sn /232; 7,3 \\
\hline 16. & Sodium/1 & Na $/ \mathbf{9 7 , 7 ; ~ 0 , 9 7 ~}$ & 51 & Antimony & Sb /630;6,62 \\
\hline 17. & Magnesium/3 & $\mathrm{Mg} / 650 ; 2,70$ & 52 & Tellurium & Te /302,5 \\
\hline 18. & Aluminium/2 & $\mathrm{Al} / 660 ; 2,70$ & 53 & Iodine & $\mathrm{J} / \mathbf{1 1 3 , 5}$ \\
\hline 19. & Silicon/4 & Si /1430; 2,33 & 54 & Xenon & Xe /-111,9 \\
\hline 20. & Phosphorus & $P / 44,1$ & 55 & Cesium/1 & $\mathrm{Cs} / 28 ; 1,9$ \\
\hline 21. & Sulfur & $\mathrm{S} / 119$ & 56 & Barium/1 & Ва /704; 3,5 \\
\hline 22. & Chlorine & $\mathrm{Cl} /-100,5$ & $\begin{array}{lll}\text { od } & 57 & \text { do } \\
71 & & \end{array}$ & Lanthanum + lant & tanides \\
\hline 23. & Argon & Ar /-189,3 & 72 & Hafnium/3 & Hf /1700; 11,4 \\
\hline
\end{tabular}


(JPMNT) Journal of Process Management - New Technologies, International Vol. 1, No.3, 2013.

\begin{tabular}{|c|c|c|c|c|c|}
\hline 24. & Potassium/1 & $\mathrm{K} / 63 ; 0,86$ & 73 & Tantalum/1 & Та /2996; 16,6 \\
\hline 25. & Calcium/2 and 3 & Ca /850; 1,55 & 74 & Volafram/1 & W /3410; 19,3 \\
\hline 26. & Scandium/2 and 3 & Sc /1200; 2,5 & 75 & Rhenium/3 & $\operatorname{Re} / 3170 ; 20$ \\
\hline 27. & Titan/3 and 1 & $\mathrm{Ti} / 1670 ; 4,51$ & 76 & Osmium/3 & Os /2700; 22,5 \\
\hline 28. & Vanadium/1 & V /1735; 6,0 & 77 & Iridium/2 & Ir /2454; 22,5 \\
\hline 29. & Chrome/1 & Cr /1890; 7,19 & 78 & Platinum/2 & Pt /1773; 21,5 \\
\hline 30. & Manganese/2 & Mn /1245; 7,43 & 79 & Gold/2 & Au /1063; 19,3 \\
\hline 31. & Iron/1 and 2 & Fe /1539; 7,87 & 80 & Mercury & $\mathrm{Hg} /-38,9 ; 13,6$ \\
\hline 32. & Cobalt/3 and 2 & Co /1495; 8,9 & 81 & Thallium/3 and 1 & $\mathbf{T l}$ \\
\hline 33. & Nickel/2 & $\mathrm{Ni} / 1455 ; \mathbf{8 , 9}$ & 82 & Lead/2 & $\mathrm{Pb} / 327 ; 11,3$ \\
\hline 34. & Copper/2 & $\mathrm{Cu} / 1083 ; 8,96$ & 83 & Bismuth & Bi /271; 9,8 \\
\hline 35. & Zinc/4 & $\mathrm{Zn} / 419 ; 7,13$ & 84 & Polonium & Po /594 \\
\hline 36. & Gallium & Ga /29; 5,91 & 85 & Astatine & At \\
\hline 37. & Germanium/4 & Ge /958; 5,36 & 86 & Radon & $\mathbf{R n} /-71$ \\
\hline 38. & Arsenic & As $/ 814 ; 5,73$ & 87 & Francium & Fr \\
\hline 39. & Selenium & Se /220 & 88 & Radium & Ra $/ 700 ; 5,0$ \\
\hline 40. & Bromine & Br $/-7,3$ & \multirow{6}{*}{\multicolumn{3}{|c|}{$\begin{array}{l}\text { *Label with the name of the element, eg. Iron/1 } \\
\text { and } 2 \text { - represent a type of crystal lattice; } \\
\text { Lattice tags: } 1 \text { - centered cubic lattice, } 2 \text { - surface } \\
\text { centered cubic lattice, } 3 \text { - complex hexagonal } \\
\text { grid, } 4 \text { - Zn and Cd grid. } \\
\text { ** Label next to element represent the melting } \\
\text { point }\left({ }^{\circ} \mathrm{C}\right) \text { and specific gravity }\left(\mathrm{g} / \mathrm{cm}^{3}\right) ; \text { ex. Iron } \\
\text { Fe/1539 }{ }^{\circ} \mathrm{C}, 7,87\left(\mathrm{~g}^{\circ} \mathrm{cm}^{3}\right)\end{array}$}} \\
\hline 41. & Krypton & Kr /-157,2 & & & \\
\hline 42. & Rubidium/1 & Rb /39; 1,53 & & & \\
\hline 43. & Strontium/2 & Sr $/ 770 ; 2,6$ & & & \\
\hline 44. & Yttrium/3 & Y /1490; 5,51 & & & \\
\hline 45. & Zirconium/3 and 1 & Zr / 1850; 6,51 & & & \\
\hline
\end{tabular}




\section{LITERATURE}

26. A.Bramnjel, (1989), Ekology in the 20 the century a history, Yale University Press, New Hawen an London.

27. Andre, M.P., i Ž. Mitrović (1996), Osnove modela ekološkog sistema, Yupiq, Kultura,Beograd.

28. Annon., Onsite (1980) Wastewater Treatment and Disposal Svstems. EPA/625/1-80/012. VV'ashington DC 20460.

29. Barkley, A (2002),Organic food growth, Department of Agricultural Economics, Kansas State University, USA.

30. Baumgarten H., Wiendahl H, Zentes J, (2002) "Logistik-Management", Band 1 i 2, Springer Verlag , Berlin Heidelberg.

31. Division for Sustainable Development (2001), Indicators and Sustainable Development: Guidelines and methodologies, United Nations, Washington.

32. Draft International Standard ISO/DIS 14041. ISO, Switzerland, (1997).

33. Edwards-Jones, G., and B. Davies, S. Hussain, (2000), Ecological Economics: anintroduction. London, Blackwell Science.

34. Gereke, Z. (1995),Ekologija i organizacija, Beograd, Znamen.

35. Gereke, Z., iV. Filipović (1994), "Ekologija kao generator novih tržišnih zaokreta". SymOrg'94, III međunarodni simpozijum"Menadžment na pragu XXI veka", Zbornik radova II, Fakultet Organizacionih Nauka, Zlatibor.
36. Tylecot, A., Straten, van Der, J. (1997),Introduction Ecology, Technology and Institutions, Edward Elgar, London.

37. Tyler G. (1981), Heavy metals in soil: Biology and biochemestry, 5: 371-413.

38. Veselinović D., Gržetić I., Đarmati Š., Marković D., (1995), Stanje i procesi u životnoj sredini, Fakultet za fizičku hemiju, Univerziteta u Beogradu, Beograd.

39. Roberts, R. (2005),Implementacija sistema ekološkog menadžmenta ISO 14001: 2004, prevod, Mobes quality, Novi Sad.

40. S. Stefanović, LJ. Stošić Mihajlović, V. Vučić, P. Jevtić (2013), Menadžment u zaštiti životne sredine,TQM Centar, Zrenjanin.

41. Sawyer, C.N., McCartv, P.L., Parkin, G.F. (1994) Chemistry for Environmental Engineering, McGravv-Hill, Inc.

42. Stefanović S., Cvejić R., (2010),Ekološki menadžment, TQM Centar, Zrenjanin.

43. Stefanović S., Šubara N. i dr. (2008), Ekološki rizici - Uticaj negativnih faktora na kvalitet života, Instutut za energetiku i ekologiju „TEHDIS“, Zrenjanin.

44. Stevenson, E. Kenneth., Bernard, T. Dane. (1995),HACCP Establishing Hazard Analysis Critical Control Point Programs. A workshop manual. Second edition, The Food processors Institute. Washington. USA.

45. Šubara N., Stefanović S., i dr. (2008), "Saobraćajna ekologija", Društvo za energetsku efikasnost, Banja Luka.

46. Šubara N.,Stefanović S. (2008), "Ekološka logistika", Društvo za tehničku dijagnostiku, Beograd.

47. Tibbs, B., C. (1992),Industrial ecology, An environmental agenda for industry, USA. 